\title{
Bacterial Examination of Wild and Cultured Fish Present in the Same Aquatic Ecosystem, and the Antibiotic Resistance of the Isolated Bacteria
}

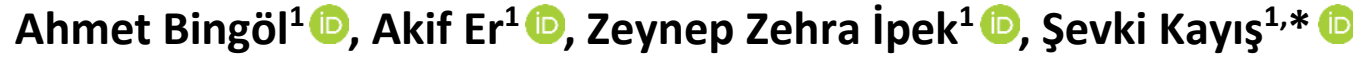 \\ ${ }^{1}$ Recep Tayyip Erdoğan University, Faculty of Fisheries Sciences, 53100, Rize, Turkey.
}

\begin{abstract}
How to cite
Bingöl, A., Er, A., İpek, Z.Z., Kayış, Ş. (2022). Bacterial Examination of Wild and Cultured Fish Present in the Same Aquatic Ecosystem, and the Antibiotic Resistance of the Isolated Bacteria. Genetics of Aquatic Organisms, 6(1), GA385. http://doi.org/10.4194/GA385
\end{abstract}

\section{Article History}

Received 11 March 2021

Accepted 08 June 2021

First Online 22 June 2021

\section{Corresponding Author}

Tel.: +9005054525663

E-mail: sevki.kayis@erdoğan.edu.tr

\section{Keywords}

Trout

Georgian shemaya

Bacteria

Antibiotics

\begin{abstract}
This study investigated the bacteria present in natural and cultured fish species from the same aquatic system, and difference of their antibiotic resistance. A total of 129 fish, Georgian shemaya (Alburnus derjugini), black sea salmon (Salmo labrax) and rainbow trout (Oncorhynchus mykiss), were sampled on a monthly basis between the months of October 2016 and September 2017 in Kürtün Dam Lake. A total of 41 bacterial isolates were isolated from the fishes. The bacterial species were identified by molecular methods (PCR) using universal primers for bacteria. Acinetobacter /woffii, Acinetobacter sp., Aeromonas sobria, and Pseudomonas sp. were isolated from both wild and cultured fish. Yersinia ruckeri was isolated from cultured fish, which showed severe mortality rate and typical symptoms. Various antibiotics including ampicillin (AMP10 $\mu \mathrm{g})$, gentamicin (CN10 $\mu \mathrm{g})$, oxytetracycline (T30 $\mu \mathrm{g})$, amoxicillin/clavulanic acid (AMC10 $\mu \mathrm{g}$ ), enrofloxacin (ENR5 $\mu \mathrm{g}$ ), trimethoprim/sulfamethoxazol (TMP-SMZ25 $\mu \mathrm{g}$ ),

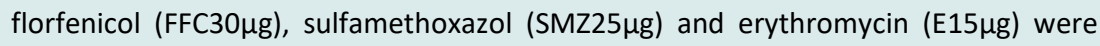
used for determination of the bacterial resistances. The highest resistances were determined against ampicillin (56\%), sulfamethoxazol (46.3\%) and oxytetracycline (34.1) in all bacterial isolates. While the bacteria isolated from wild fish did not show resistance to enrofloxacin and amoxicillin/clavulanic acid, those from cultured fish did not show resistance to gentamicin and erythromycin.
\end{abstract}

\section{Introduction}

All factors affecting fish health are considered important in aquaculture (Timur and Timur 2003). When fish from the natural environment are compared to those from cultured conditions, the former ones are found to be healthier because they are safe from stress factors in their natural environment. However, it does not mean that cultured fish are always prone to infection or disease. When diseases are examined in natural fish species, it can be observed that some natural fish stocks are infected by pathogens, which causes the loss of a significant number of natural fish (Heil et al., 2001).

Several researchers in various geographic regions of the world have made reports similar to this study. For example, Sockeye salmon (Oncorhynchus nerka), which lives in the natural systems of Canada's west coast, was observed to have external lesions and severe mortality caused by a Caligid parasite species named Lepeophtheirus salmonis (Johnson et al 2011). Another similar study was that of the mass deaths of natural 
mullet fish in the Arab Gulf (Heil et al., 2001). In this study, it was reported that the mass deaths of natural mullet fish (Liza klunzingeri) were caused by the bacterium Streptococcus agalactiae. Other studies have reported mass fish deaths in natural aquatic areas owing to excessive plankton blooms (Brusle 1993). Poor health and illness in cultured fish have also frequently been reported. Several diseases caused by various pathogenic groups, or by nutritional or other factors, have been reported in various economically important fish species (Öztürk and Altınok 2014).

In recent years, a new subject has begun to attract the attention of fish pathologists, which is the dissemination of infective agents between wild and cultivated fish species present in the same aquatic areas. Several studies have shown that this relationship has a complex structure (Oliver and MacKinnon 1998). Some researchers reported that the pathogens of cultured and wild salmon (Salmo salar) from the same environment are interconnected. They investigated the presence of bacterial, parasitic, and viral pathogens in wild and cultivated sea bass from the Adriatic Sea (Coz-Rakovic et al 2002). Similarly, a few researchers observed not only the transfer of various groups of pathogens between salmon and other natural species grown in Norway but also that this transfer occurred in both ways (Johnson et al 2011).

In order to achieve sustainable aquaculture, the pathogens transferred between cultured and wild fish species should be known. In this article, we have determined the bacterial pathogens in a wild carp species Georgian shemaya (Alburnus derjugini) and cultivated trout species (Salmo labrax and Oncorhynchus mykiss) present in the same aquatic system. Also, we have compared the antibiotic resistance of all the isolated bacteria.

\section{Material and Methods}

The aquatic ecosystem selected for this study was the Kürtün dam lake located in the Eastern Black Sea region of Turkey (Figure 1). Trout farming practices have been carried out in the Kürtün dam lake since 2008. Some wild carp species were also found to be present there. A total of 129 fish belonging to three different species were sampled on a monthly basis from October, 2016 to September, 2017. Of these, 50 wild cyprinid species Georgian shemaya (Alburnus derjugini) $(11.58 \pm 2.96 \mathrm{~cm} / 19.42 \pm 11.45 \mathrm{~g}), 56$ cultured fish çoruh trout (Salmo labrax) $(19.43 \pm 5.55 \mathrm{~cm} / 108.28 \pm 97.68 \mathrm{~g})$ and 23 cultured rainbow trout (Oncorhynchus mykiss) $(20.68 \pm 4.25 \mathrm{~cm} / 124.11 \pm 78.99 \mathrm{~g})$, (mean \pm SD) were sampled for bacterial examination. Wild fish were captured by fishnets near the cage of cultured fish at a depth of 0-20 meters. The dam lake water temperature and $\mathrm{pH}$ values were measured using a portable handheld $\mathrm{pH}$ meter (Isolab). In the same way, values for all months of the year were obtained. Bacteriological examination was performed on the captured fish, from vital organs of the fish like kidney, spleen, and liver. Tryptic soy agar (TSA) medium (Lasee 1995) used for this purpose and medium were incubated at $22^{\circ} \mathrm{C}$ for $24-48$ h. Pure bacterial isolates were sub-cultured and stocked in tubes containing $15 \%$ glycerol at $-70{ }^{\circ} \mathrm{C}$ for further analysis.

Bacterial identification was done by observing the morphological characteristics (colony colors and shapes). Mobility, Gram stain, oxidase, and catalase tests were also performed. Further, the isolates were inoculated in Glutamate Starch Phenol Red (GSP) agar. The resulting yellow- and purple-colored colonies were identified as Aeromonas sp. and Pseudomonas sp., respectively (Cappuccino and Sherman 2014).

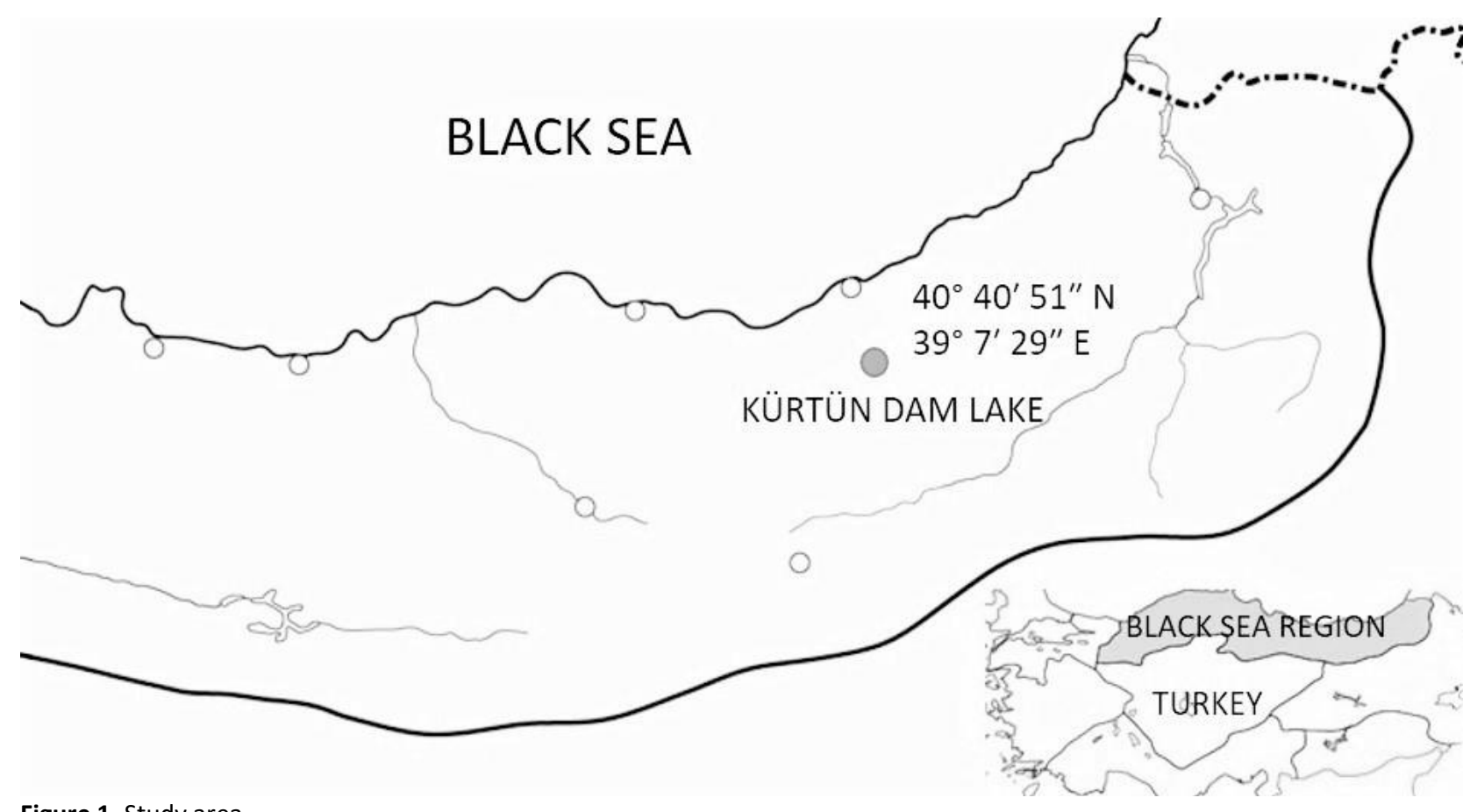

Figure 1. Study area 
Molecular identification of the bacteria was performed by analysis of the bacterial DNA. The boiling method was applied for the isolation of DNA from Gramnegative bacteria, whereas commercial DNA isolation kits (QIAamp DNA Microbiome Kit, QIAGEN), were used for the extraction of DNA from Gram-positive bacteria (only one bacterial species was Gram-positive) (Dashti, et al., 2009). Universal primers specific to the $16 \mathrm{~S}$ rRNA region of eubacteria (27 Fwd 5'-AGA GTT TGA TCC TGG CTC AG-3', 1492 Rev 5'-GTT TAC CTT GTT ACG ACT T-3') were used for implication. A PCR reaction was set up using bacterial genomic DNA (25 ng) and the given primers $(2.0 \mu \mathrm{L}$ of each primer) (Model Px2 ThermoHybrid; Thermo Electron Inc., Waltham, MA, USA). The resulting $1465-b p$ amplified product was purified with a NucleoSpin PCR purification kit (Macherey-Nagel), and sent for sequencing by doublesided reading (ABI PRISM 310 genetic analyzer, Applied Biosystems). The results were compared to known data (http://www.ncbi.nlm.nih.gov) for the identification of the bacteria.

For the determination of the antibiotic resistance of bacteria, bacterial isolates were inoculated on Tryptic Soy Agar medium at $22^{\circ} \mathrm{C}$ for $24 \mathrm{~h}$. After the formation of colonies, the colonies were transferred to Mueller Hinton Agar medium with in Phosphate Buffered Saline solution (PBS). Bacterial density was determined following the McFarland 0.5 standard (Zapata and Ramirez-Arcos, 2015). All procedures were carried out aseptically according to Clinical and Laboratory Standards Institute (CLSI 2014) guidelines. Antibiotic discs were placed on the medium with bacteria, and the plates were incubated at $22 \pm 2 \circ \mathrm{C}$ for $18-36 \mathrm{~h}$. The resulting zone diameters were recorded as resistant (R) or sensitive (S) according to CLSI (2014) directive.

The study protocol was approved by Recep Tayyip Erdoğan University Local Ethics Committee of Animal Trials in advance with the approval number of 2016/31

\section{Results}

The temperature and $\mathrm{pH}$, recorded on a monthly basis, for the water of Kürtün Dam lake, are given in Figure 2. According to the recorded values, the highest water temperature was measured in August (24ㅇ) ), and the lowest water temperature was measured in February $\left(7.1^{\circ} \mathrm{C}\right)$. The $\mathrm{pH}$ values were generally the same throughout the year except in August (8.3) and September (8.16), when it was higher than in the other months.

A total of 27 bacterial isolates were obtained from Alburnus derjugini, whereas 14 bacterial isolates were isolated from Salmo labrax and Oncorhynchus mykiss (Table 1). Aeromonas sobria, Acinetobacter Iwoffii, Acinetobacter sp., and Pseudomonas sp. were isolated from both groups. From wild fish alone, bacteria of the genera Acidovorax, Lelliottia, and Shewanella were isolated (Table 2). From cultured fish, bacteria of the genera Bacillus, Citrobacter, and Escherichia were isolated (Table 3). All bacteria were Gram-negative except Bacillus simplex. During the study period, only Yersinia ruckeri infection was observed in rainbow trout (Figure 3). In all the bacterial isolates, the highest antibiotic resistance was determined against ampicillin (56\%). Following ampicillin, the highest resistance was recorded against sulfamethoxazol (46.3\%). The lowest

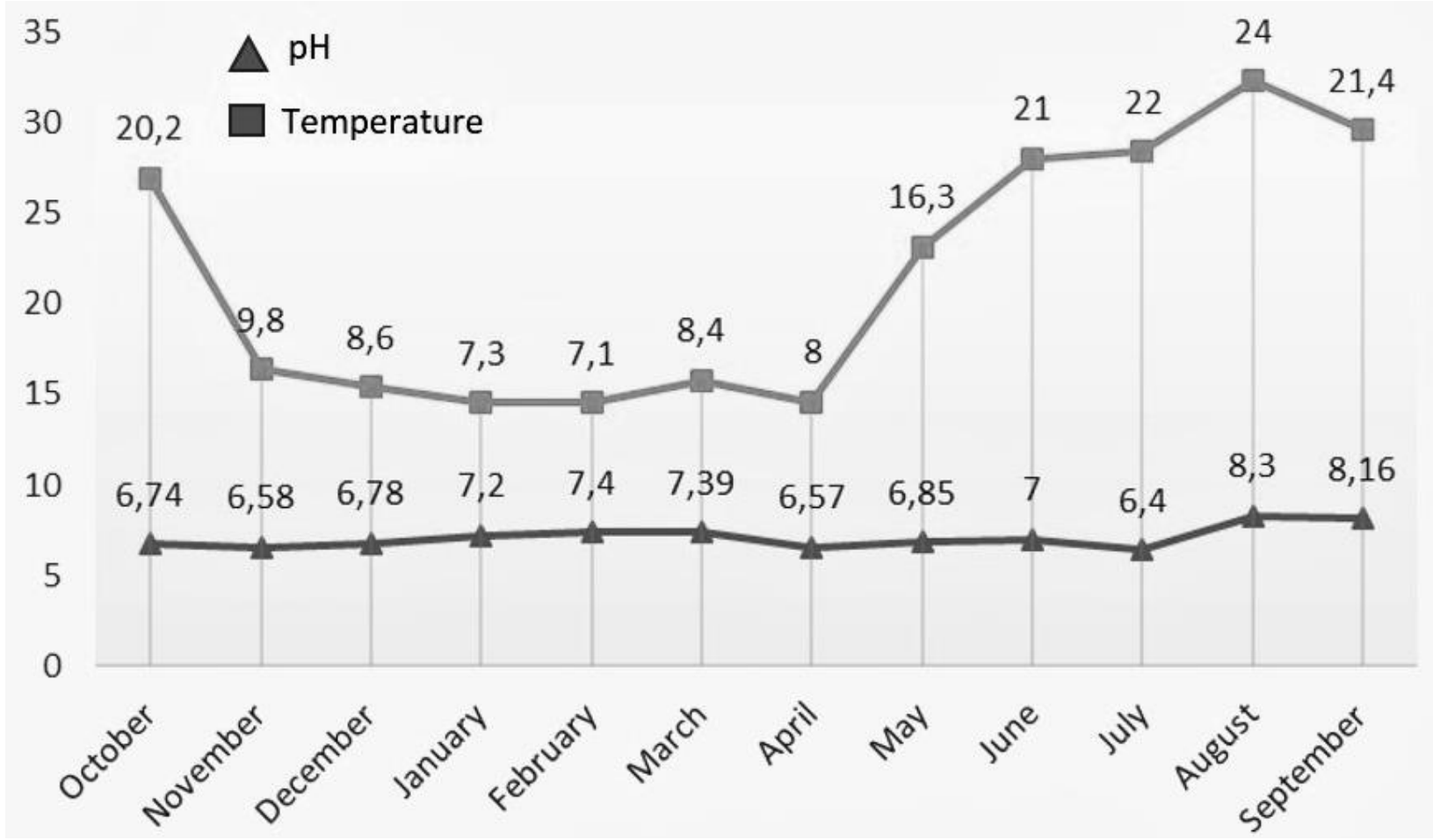

Figure 2. Temperature and $\mathrm{pH}$ values of the water measured during a year 
Table 1. Bacteria isolated from cultured and wild fish. S: Summer, Sp: Spring, W: Winter, A: Autumn

\begin{tabular}{|c|c|c|c|c|c|c|c|c|c|c|}
\hline \multicolumn{5}{|c|}{ Alburnus derjugini } & \multirow[t]{2}{*}{ Bacteria (n) } & \multicolumn{5}{|c|}{ S. labrax and O. mykiss } \\
\hline$S$ & Sp & W & A & & & & A & W & Sp & $\mathrm{S}$ \\
\hline- & - & - & 1 & & Acinetobacter sp. & & 1 & 2 & - & 1 \\
\hline- & 2 & - & - & & Aeromonas sobria & & 1 & - & - & - \\
\hline- & - & - & 2 & & Acinetobacter Iwoffii & & - & 1 & - & - \\
\hline- & - & 1 & 1 & & Pseudomonas sp. & & - & 2 & - & - \\
\hline- & 1 & - & - & Acidovorax wohlfahrtii & & Acinetobacter johnsonii & - & 1 & - & - \\
\hline 1 & 1 & - & 1 & Aeromonas veroni & & Bacillus simplex & 1 & - & - & - \\
\hline- & - & - & 1 & Aeromonas allosaccharophila & & Citrobacter freundii & - & - & - & 1 \\
\hline- & - & - & 1 & Aeromonas hydrophila & & Escherichia vulneris & - & 1 & - & - \\
\hline- & 1 & 1 & - & Aeromonas salmonicida & & Pseudomonas fulva & 1 & - & - & - \\
\hline- & 1 & - & 1 & Aeromonas sp. & & Yersinia ruckeri & - & - & - & 1 \\
\hline 1 & - & - & - & Lelliottia amnigena & & & & & & \\
\hline 4 & - & - & - & Lelliottia nimipressuralis & & & & & & \\
\hline 1 & - & - & - & Lelliottia sp. & & & & & & \\
\hline- & 1 & - & - & Shewanella baltica & & & & & & \\
\hline- & 1 & - & - & Shewanella putrefaciens & & & & & & \\
\hline- & 1 & - & - & Shewanella sp. & & & & & & \\
\hline- & - & - & 1 & Yersinia sp. & & & & & & \\
\hline
\end{tabular}

Table 2. Bacteria isolated from Alburnus derjugini and their accession number

\begin{tabular}{|c|c|c|c|c|}
\hline Cod & Bacteria & $\%$ & Similarity & Accession \\
\hline K1 & Aeromonas allosaccharophila & 99 & KC202277.1 & MK548513 \\
\hline K2 & Aeromonas sp. & 99 & KF317749.1 & MK548514 \\
\hline K4 & Yersinia sp. & 99 & KR072681.1 & MK548515 \\
\hline K6 & Aeromonas salmonicida & 99 & KU359246.1 & MK548516 \\
\hline K7 & Pseudomonas sp. & 99 & KX301316.1 & MK548517 \\
\hline K9 & Acidovorax wohlfahrtii & 99 & KC178583.1 & MK548518 \\
\hline K11 & Shewanella baltica & 99 & KF193912.1 & MK548519 \\
\hline K12 & Aeromonas salmonicida & 99 & KU359246.1 & MK548520 \\
\hline K13 & Pseudomonas sp. & 99 & KP671491.1 & MK548521 \\
\hline K14 & Shewanella putrefaciens & 99 & KX817288.1 & MK548522 \\
\hline K15 & Shewanella sp. & 99 & KF193912.1 & MK548523 \\
\hline K16 & Aeromonas sp. & 99 & KF317749.1 & MK548524 \\
\hline K17 & Aeromonas veroni & 96 & JF920551.1 & MK548525 \\
\hline K18 & Aeromonas sobria & 92 & LC198517.1 & MK548526 \\
\hline K19 & Aeromonas veroni & 99 & JX501708.1 & MK548527 \\
\hline K20 & Aeromonas sobria & 99 & KY767507.1 & MK548528 \\
\hline K21 & Lelliottia sp. & 99 & KM458060.1 & MK548529 \\
\hline K22 & Lelliottia nimipressuralis & 99 & КT986079.1 & MK548530 \\
\hline K23 & Lelliottia nimipressuralis & 99 & КT986079.1 & MK548531 \\
\hline K24 & Lelliottia nimipressuralis & 99 & КT986079.1 & MK548532 \\
\hline K25 & Lelliottia amnigena & 99 & КT986085.1 & MK548533 \\
\hline K26 & Lelliottia nimipressuralis & 99 & КT986079.1 & MK548534 \\
\hline K28 & Acinetobacter sp. & 99 & KC294105.1 & MK548535 \\
\hline K30 & Aeromonas veroni & 99 & KY767507.1 & MK548536 \\
\hline K31 & Aeromonas hydrophila & 99 & KC202281.1 & MK548537 \\
\hline K32 & Acinetobacter Iwoffii & 99 & KC139416.1 & MK548538 \\
\hline K34 & Acinetobacter Iwoffii & 99 & MF988732.1 & MK548539 \\
\hline
\end{tabular}

Table 3. Bacteria isolated from cultured fish and their accession number.

\begin{tabular}{|c|c|c|c|c|}
\hline Cod & Bacteria & $\%$ & Similarity & Accession \\
\hline KY1 & Aeromonas sobria & $\% 99$ & KT456272.1 & MK548497 \\
\hline KY2 & Pseudomonas sp. & $\% 99$ & KF153215.1 & MK548498 \\
\hline KY3 & Pseudomonas sp. & $\% 99$ & FJ999660.1 & MK548499 \\
\hline KY4 & Acinetobacter johnsani & $\% 99$ & KY767497.1 & MK548500 \\
\hline KY5 & Acinetobacter Iwoffii & $\% 99$ & KC456554.1 & MK548501 \\
\hline KY6 & Acinetobacter sp. & $\% 99$ & KY962740.1 & MK548502 \\
\hline KY7 & Escherichia vulneris & $\% 99$ & NR114080.1 & MK548503 \\
\hline KY9 & Acinetobacter sp. & $\% 99$ & GU977189.1 & MK548504 \\
\hline KY12 & Acinetobacter sp. & $\% 99$ & KX639781.1 & MK548506 \\
\hline KY15 & Citrobacter freundii & $\% 99$ & MF716709.1 & MK548508 \\
\hline KY17 & Yersinia ruckeri & $\% 99$ & KJ812974.1 & MK548507 \\
\hline KY20 & Pseudomonas fulva & $\% 99$ & FJ972539.1 & MK548510 \\
\hline KY22 & Bacillus simplex & $\% 99$ & GU188923.1 & MK548511 \\
\hline KY23 & Acinetobacter sp. & $\% 94$ & KY305017.1 & MK548512 \\
\hline
\end{tabular}


antibiotic resistance was determined against gentamicin, amoxicillin/clavulanic acid, and enrofloxacin (2.1\%) in all bacterial isolates (Figure 4 ). This led to the conclusion that bacteria isolated from carp, which are a natural species, did not show resistance to enrofloxacin and amoxicillin/clavulanic acid antibiotics. On the other hand, bacteria isolated from cultured fish did not show resistance to gentamicin and erythromycin.

\section{Discussion}

Temperature and $\mathrm{pH}$ values are important water quality parameters that influence fish pathogens similar to other organisms. These factors affect the intensity, prevalence, and virulence of the parasitic and bacterial fish pathogens (Timur and Timur 2003; Woo 2006). The sampled fishes in the present study were from different
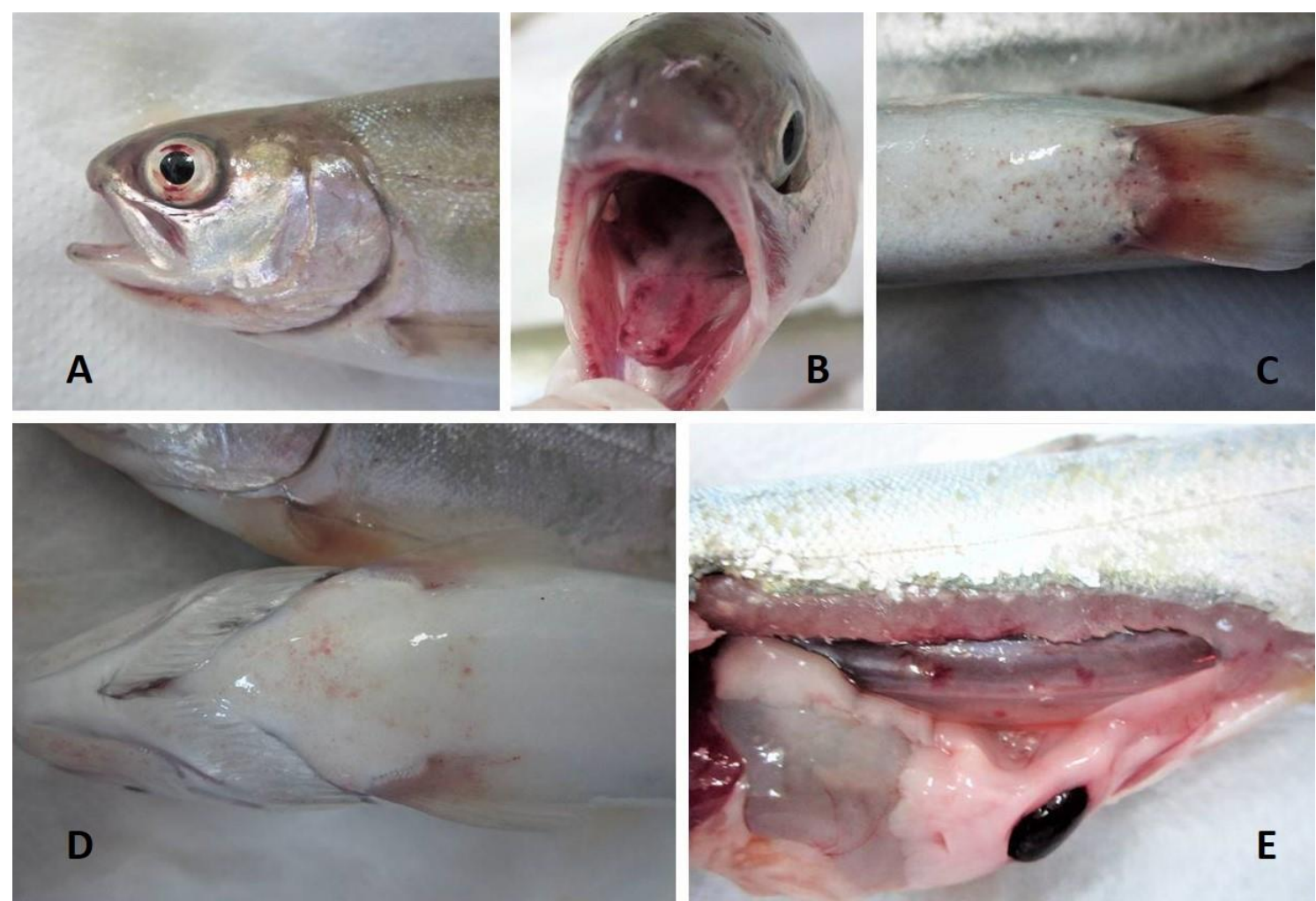

Figure 3. Typical symptoms of enteric redmouth diseases caused by Yersinia ruckeri. Hemorrhage in the eyes and mouth (A, B), petechial hemorrhage on the skin and gas bladder $(C, D, E)$.

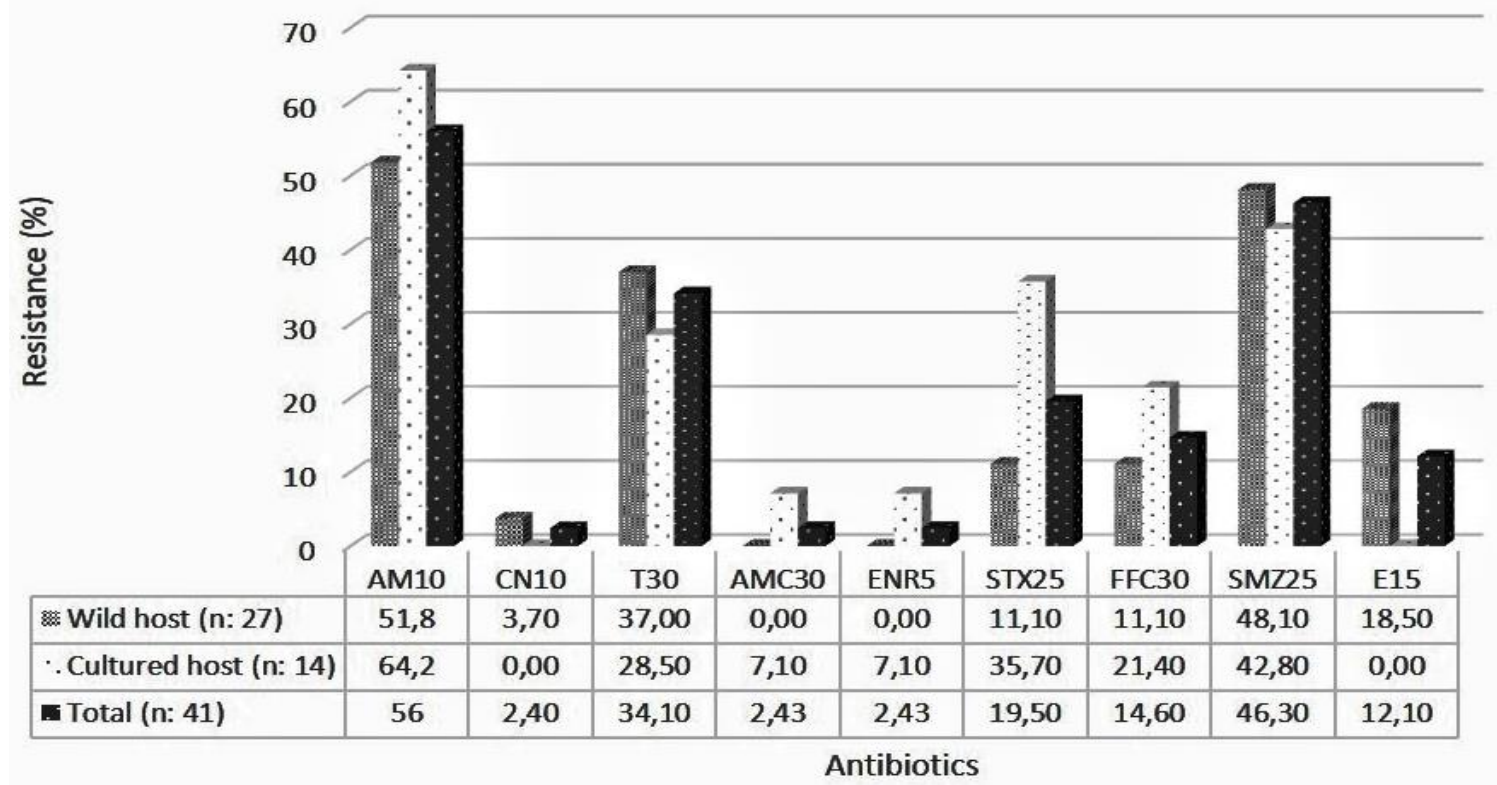

w Wild host (n: 27) . Cultured host ( $:$ 14) - Total (n: 41)

Figure 4. Bacterial resistance against different antibiotics 
genera. The water temperature and $\mathrm{pH}$ values recorded in this study were within the limit. Hence, it is safe to assume that these values would not have affected the host selection of pathogens.

When bacteria isolated from the two fish groups were evaluated, many varied bacterial species were observed. Motile and nonmotile Aeromonas species have previously been reported in different fish species (Austin and Austin 2007). A. sobria and A. veroni were isolated from both cultured and wild fish. A. hydrophila and $A$. salmonicida, which have mostly been reported in cultured fish and salmonid fish, have also been isolated from wild fish. However, the presence of Aeromonas species in both groups indicates a high probability of bacterial contamination between wild and cultured species. A similar situation has been observed in the case of Acinetobacter sp.

Lelliottia bacterial species is generally found in soil and nutrients, but usually not in fish. The bacteria of Lelliottia genus are Gram-negative, mobile, and rodshaped. L. nimipressuralis is mostly found in plants, and L. amnigena is used as a marker for the detection of food contamination. In a recent study, L. nimipressuralis was found in the blood tissue of humans (Yuk et al 2018). The unlikely the presence of Lelliottia bacteria in fish may be caused by a constant change in the elevation level of dam water for electricity generation. When the water level goes up to 25-30 m in the dam, it comes in contact with plants and soil. As cultured fish are reared in deep water columns, they are unlikely to get a bacterial infestation. Lelliottia bacteria can be isolated from natural fish species only during the summer, and the dissemination of bacteria from wild to cultured fish may not be possible in a short period. Therefore, these bacteria were not detected in cultured fish.

Yersinia ruckeri bacterium was isolated from trout in the 1950s for the first time in the USA (Ross et al 1966), and later, it was isolated throughout Europe (Austin and Austin 2007). It is usually found in rainbow trout and perch in Turkey (Öztürk and Altınok 2014). Yersinia ruckeri can infect different fish species, including trout such as carp, catfish, sturgeon, and perch (Kumar et al 2015). In this study, severe mortality of rainbow trout was observed during summer months caused by Yersinia ruckeri. Another species of Yersinia was also isolated from the wild fish Alburnus derjugini.
These results indicate that Yersinia species can be a common threat to cultured and wild fish present in the same area.

Antibiotics are commonly used in the aquaculture sector for bacterial disease treatment. Apart from this, the terrestrial use of antibiotics causes their final accumulation in the water. Therefore, bacterial resistance can occur in bacteria isolated not only from reared fish but also from other system components such as various aquatic organisms, water, and sediment (Harvey et al 2006; Terzi 2018; Terzi and Işler 2019). It is very important to examine bacterial resistance levels in sustainable aquatic environments. Data from this study provided the information necessary to determine the effects of aquaculture activities on aquatic environments, where aquaculture practices are carried out, especially with regard to antibiotic resistance. An important finding in this study was the absence of sensitivity to the same antibiotics between the two bacterial groups. Thus, the bacterial groups were (100\%) sensitive to different antibiotics. For example, bacteria isolated from wild fish were found to be sensitive to amoxicillin/clavulanic acid and enrofloxacin.

On the other hand, bacteria isolated from cultured fish were sensitive to gentamicin and erythromycin. Similar resistance was recorded in all bacteria against ampicillin and sulfamethoxazole. Among the four bacterial species isolated from both fish groups, only Pseudomonas sp. was observed to show some differences in antibiotic resistance. The Pseudomonas sp. strains isolated from wild fish were found to be more resistant than those from cultured fish. Other bacteria were similar in their bacterial resistances (Table 4).

\section{Conclusion}

All findings in this study showed that bacterial contamination between wild and cultured fish present in the same aquatic system is not strongly interactive. The antibiotic resistance of bacteria isolated from the two fish groups can also be evaluated in the same manner. Taking these findings into account, it should be noted that this hypothesis can hold true only for this study and the chosen aquatic system. More studies need to be conducted in other aquatic systems to determine if similar trends can be observed in those studies.

Table 4. Bacterial resistances against antibiotics isolated from cultured and wild fish. $H$, host, N, number, W, wild host, $C$, cultured fish

\begin{tabular}{|c|c|c|c|c|c|c|c|c|c|c|c|}
\hline \multirow{3}{*}{ Bacteria } & \multirow{3}{*}{$\mathrm{H}$} & \multirow{3}{*}{$\mathrm{N}$} & \multicolumn{9}{|c|}{ Antimicrobials } \\
\hline & & & AM & $\mathrm{CN}$ & $\mathrm{T}$ & AMC & ENR & SXT & FFC & SMZ & $E$ \\
\hline & & & 10 & 10 & 30 & 30 & 5 & 25 & 30 & 25 & 15 \\
\hline \multirow{2}{*}{ Pseudomonas sp. } & W & 2 & $\mathrm{R}$ & $\mathrm{S}$ & $R / S$ & $\mathrm{~S}$ & $S$ & $\mathrm{R} / \mathrm{S}$ & $\mathrm{R}$ & $\mathrm{R}$ & $\mathrm{R} / \mathrm{S}$ \\
\hline & $\mathrm{C}$ & 2 & $\mathrm{R}$ & $\mathrm{S}$ & $\mathrm{S}$ & $\mathrm{S}$ & $\mathrm{S}$ & $\mathrm{S}$ & $S$ & $\mathrm{~S}$ & $\mathrm{~S}$ \\
\hline \multirow{2}{*}{ Aeromonas sobria } & W & 2 & $R / S$ & $S$ & $R / S$ & $S$ & $S$ & $S$ & $S$ & $S$ & $\mathrm{R} / \mathrm{S}$ \\
\hline & $\mathrm{C}$ & 1 & $\mathrm{R}$ & $\mathrm{S}$ & $\mathrm{R}$ & $\mathrm{S}$ & $\mathrm{S}$ & $\mathrm{R}$ & $\mathrm{S}$ & $\mathrm{R}$ & $S$ \\
\hline \multirow{2}{*}{ Acinetobacter sp. } & W & 1 & $\mathrm{~S}$ & $\mathrm{~S}$ & $S$ & $\mathrm{~S}$ & $S$ & $\mathrm{~S}$ & $S$ & $\mathrm{R}$ & $S$ \\
\hline & $\mathrm{C}$ & 4 & $\mathrm{R} / \mathrm{S}$ & $\mathrm{S}$ & $S$ & $\mathrm{~S}$ & $S$ & $S$ & $S$ & $\mathrm{R} / 3 \mathrm{~S}$ & $S$ \\
\hline \multirow{2}{*}{ Acinetobacter Iwoffii } & $W$ & 2 & $\mathrm{~S}$ & $\mathrm{~S}$ & $\mathrm{R} / \mathrm{S}$ & $\mathrm{S}$ & $\mathrm{S}$ & $\mathrm{S}$ & $\mathrm{R}$ & $\mathrm{R}$ & $\mathrm{R} / \mathrm{S}$ \\
\hline & $C$ & 1 & $\mathrm{~S}$ & $\mathrm{~S}$ & $\mathrm{~S}$ & $\mathrm{~S}$ & $S$ & $\mathrm{~S}$ & $\mathrm{~S}$ & $\mathrm{~S}$ & $\mathrm{~S}$ \\
\hline
\end{tabular}




\section{Ethical Statement}

In this study, all applications related to fish were carried out in accordance with the permission and directives of the ethics committee of Republic of Turkey Recep Tayyip Erdogan university Local Ethics Committee for Animal Experiments (Decision no: 2016/31).

\section{Funding Information}

This study was funded by the Recep Tayyip Erdogan University Research Project Fund (Project No. FYL-2016682).

\section{Author Contribution}

A.B.: Designed the study and interpreted data.

A.E.: Performed the laboratory work.

Z.Z.i.: Performed the laboratory work. writing

Ş.K.: Designed the study and interpreted data and

\section{Conflict of Interest}

The authors of the study have no conflicts of interest to declare.

\section{Acknowledgements}

This study was funded by the Recep Tayyip Erdoğan University Research Project Fund (Project No. FYL-2016682).

\section{References}

Austin, B., \& Austin D.A. (2007). Bacterial fish pathogens: Disease of Farmed and Wild Fish, pp. 220 4th Ed. Chichester, United Kingdom, Springer Praxis Publishing,

Brusle, J. (1993). The impact of harmful algal blooms on finfish occurrence of fish kills, pathology, toxicological mechanisms, ecological and economic impacts. 6 e Conférence Internationale Sur Le Phytoplancton Marin Toxique. (pp 55-75). Nantes, France,

Cappuccino, J.G., \& Sherman, N. (2014). Microbiology, A Laboratory Manual. In Cappuccino, J.G. \& Sherman, N. (Eds.), Biochemical activities of microorganisms (pp 153216) California, USA. The Benjamin/Cummings Publishing Co.

CLSI. (2014). Clinical and laboratory standards institute. Performance standards for antimicrobial susceptibility testing, 17.

Coz-Rakovic, R., Strunjak-Perovic, I., Topic Popovic, N., Hacmanjek, M., Šimpraga, B., \& Teskeredžić, E. (2002). Health status of wild and cultured sea bass in the Northern Adriatic Sea. Northern Adriatic Sea. Veterinarni Medicina Czech, 47(8), 222-226. https://doi.org/10.17221/5828-VETMED

Dashti, A.A, Jadaon M.M., Abdulsamad A.M, \& Dashti H.M. 2009. Heat Treatment of Bacteria: A Simple Method of
DNA Extraction for Molecular Techniques. Kuwait Medical Journal, 41(2): 117-122.

Harvey, R.A., Champe, P.C., Mycek M.J. \& Champe, P.C. (2006). Pharmacology. Lippincott Williams\&Wilkins, ISBN-10: 0781724139, 477s.

Heil, C.A., Glibert P.M., Al-Sarawi M.A., Faraj M., Behbehani M. \& Husain M. (2001). First record of a fish-killing Gymnodinium sp. bloom in Kuwait Bay, Arabian Sea: chronology and potential causes. Marine Ecology Progress Series, 214, 15-23. https://doi.org/10.3354/meps214015

Johansen, L.H., Jensen, I., Mikkelsen, H., Bjørn, P.A., Jansen, P.A. \& Berg, $\varnothing$. (2011). Disease induced by the sea louse (Lepeophteirus salmonis) (Copepoda: Caligidae) in wild sockeye salmon (Oncorhynchus nerka) stocks of Alberni Inlet, British Columbia. Canadian Journal of Fisheries and Aquatic Sciences, 53, 2888-2897. https://doi.org/10.1139/f96-226

Kumar, G., Menanteau-Ledouble, S., Saleh, M. \& El-Matbouli, M. (2015). Yersinia ruckeri, the causative agent of enteric redmouth disease in fish. Veterinary Microbiology, 46, 103. https://doi.org/10.1186/s13567-015-0238-4

Lasee, B.A. (1995). Introduction to fish health management, Lester Avenue Onalaska, Wisconsin, U.S, Fish and Wildlife Service La Crosse Fish Health Centre 555, 139pp.

Olivier, G. \& MacKinnon, A.M. (1998). A review of potential impacts on-wild salmon stocks from diseases attributed to farmed salmon operations. Canadian Stock Assessment Secretariat Research Document 98/159.

Öztürk, R.Ç. \& Altınok, i. (2014). Bacterial and viral fish diseases in Turkey. Turkish Journal of Fisheries and Aquatic Sciences, 14, 275-297. https://doi.org/10.4194/13032712-v14_1_30

Ross, A.J., Rucker, R.R. \& Ewing, W.H. (1966). Description of a bacterium associated withredmouth disease of rainbow trout (Salmo gairdneri). Canadian Journal of Microbiology, 12, 763-770. https://doi.org/10.1139/m66-103

Terzi, E. (2018). Determination of Antimicrobial Resistance Profiles of the Bacteria Isolated from Cultured Sturgeons. Menba Journal of Fisheries Faculty, 4 (2), 7 13.

Terzi, E. \& İşler, H. (2019). Antibiotic resistance genes of Escherichia coli in coastal marine environment of Eastern Black Sea, (Turkey). Fresenius Environ Bulletin, 28 (2A),1594-1601.

Timur, M. \& Timur, G. (2003). Balık Hastalıkları Kitabı, TC. İstanbul Üniversitesi Yayınları, Rektörlük Yayın No: 4426, Su Ürünleri Yayın No: 5, 238, İstanbul. 108 s. (Turkish)

Woo, P.T.K (2006). Fish Diseases and Disorders, vol. 1: Protozoan and Metazoan Infections, second edition, Cambridge, MA, USA, CABI North American Office Published, 791pp. https://doi.org/10.1079/9780851990156.0000

Yuk, K.J., Kim, Y.T., Huh, C.S. \& Lee, J.H. 2018. Lelliottia jeotgali sp. nov., isolated from a traditional Korean fermented clam. International Journal of Systematic and Evolutionary Microbiology, 68(5), 1725-1731. https://doi.org/10.1099/ijsem.0.002737

Zapata, A. \& Ramirez-Arcos, S. 2015. A Comparative Study of McFarland Turbidity Standardsand the Densimat Photometer to Determine Bacterial Cell Density, Current Microbiology, 0.1007/s00284-015-0801-2. 